\title{
A cross-country analysis of the relationship between income inequality and social capital
}

Citation for published version (APA):

Heijke, J. A. M., \& loakimidis, M. (2013). A cross-country analysis of the relationship between income inequality and social capital. ROA. ROA Technical Reports No. 003 https://doi.org/10.26481/umarot.2013003

Document status and date:

Published: 01/01/2013

DOI:

10.26481/umarot.2013003

Document Version:

Publisher's PDF, also known as Version of record

\section{Please check the document version of this publication:}

- A submitted manuscript is the version of the article upon submission and before peer-review. There can be important differences between the submitted version and the official published version of record.

People interested in the research are advised to contact the author for the final version of the publication, or visit the DOI to the publisher's website.

- The final author version and the galley proof are versions of the publication after peer review.

- The final published version features the final layout of the paper including the volume, issue and page numbers.

Link to publication

\footnotetext{
General rights rights.

- You may freely distribute the URL identifying the publication in the public portal. please follow below link for the End User Agreement:

www.umlib.nl/taverne-license

Take down policy

If you believe that this document breaches copyright please contact us at:

repository@maastrichtuniversity.nl

providing details and we will investigate your claim.
}

Copyright and moral rights for the publications made accessible in the public portal are retained by the authors and/or other copyright owners and it is a condition of accessing publications that users recognise and abide by the legal requirements associated with these

- Users may download and print one copy of any publication from the public portal for the purpose of private study or research.

- You may not further distribute the material or use it for any profit-making activity or commercial gain

If the publication is distributed under the terms of Article $25 \mathrm{fa}$ of the Dutch Copyright Act, indicated by the "Taverne" license above, 
1) Maastricht University

Research Centre for Education and the Labour Market | ROA

\section{A cross-country analysis of the relationship between income inequality and social capital}

Marilou loakimidis

Hans Heijke

\section{ROA Technical Report}

ROA-TR-2013/3

Research Centre for Education and the Labour Market Maastricht University

P.O. Box 616, 6200 MD Maastricht, The Netherlands

$\mathrm{T}+31433883647 \mathrm{~F}+31433884914$

secretary-roa-sbe@maastrichtuniversity.nl www.roa.nl 


\section{A cross-country analysis of the relationship between income inequality and social capital}

Marilou loakimidis

Hans Heijke

ROA-TR-2013/3

July 2013

Research Centre for Education and the Labour Market Maastricht University

P.O. Box 616, 6200 MD Maastricht, The Netherlands

$\mathrm{T}+31433883647 \mathrm{~F}+31433884914$

secretary-roa-sbe@maastrichtuniversity.nl

www.roa.nl 


\begin{abstract}
This study investigated whether earnings inequality is associated with social capital as measured by active membership in organizations and interpersonal trust. Pearson product-moment correlation analysis showed that greater earnings inequality was associated with lower values on both measures of social capital in 14 European countries. While causality in either direction cannot be inferred from this result, it does suggest the possibility that earnings inequality negatively affects social capital. To test this idea further, we also tentatively examined whether other societal indicators related to earnings inequality are associated with social capital. These alternative indicators - the country's percentage of urban residents, percentage of residents with tertiary education, and government spending as a percentage of GDP — did not show stronger relationships with social capital than did earnings inequality. Further analysis of the data by excluding specific groups of countries indicated little association between earnings inequality and measures of social capital. These results suggested that country-specific economic or cultural values play a large role in how earnings inequality and social capital are related.
\end{abstract}

JEL classification: J31, Z13

Keywords: earnings inequality, social capital, trust, Europe

Marilou Ioakimidis

University of Peloponnesus and University of Athens

5 Thissiou str

174-55 Athens

Greece

mioakeim@econ.uoa.gr or marilou@uop.gr

Hans Heijke

Department of Economics and ROA

Maastricht University

P.O. Box 616

6200 MD Maastricht

The Netherlands

h.heijke@maastrichtuniversity.nl 


\section{Introduction}

Earnings inequality within a country is important not only to individuals and families, but may also be associated with large-scale features of the society, including its social cohesion (Barro, 2000; Wilkinson \& Marmot, 2003; European Commission, 2005). Social capital, a factor closely related to social cohesion (Lowndes, 2000; Reeskens, 2007), may also vary with income or earnings distributions, as has been indicated by the results of several studies (e.g., Growiec and Growiec, 2007; Kennedy, Kawachi, Prothrow-Stith, Lochner, \& Gupta, 1998).

In this paper we will provide further evidence on the relationship between earnings inequality and social capital. Larsen's (2006) study is of particular interest in this respect, because it examined the relation between income inequality and social capital in 20 countries characterized by having social democratic welfare regimes, conservative welfare regimes, or liberal welfare regimes. While the former two categories comprised data from 14 European countries, no former Soviet Bloc countries were included in Larsen's study. It is thus of interest to determine whether a relationship may exist between earnings inequality and social capital in a substantial set of European countries when data from several of the former Soviet Bloc countries are included. Moreover, while Larsen's study focused on the concept of income distribution, he did not investigate how the related construct, earnings distribution, might be related to social capital. ("Earnings" refers to monies in the form of wages and/or salary, while "income" includes earnings plus monies gained by individuals and households by other means, such as investment income and welfare benefits.)

To our knowledge, there have been no studies focusing on whether earnings inequality specifically is related to social capital in a sizable group of European countries that include former Soviet Bloc countries. The present study adds to the literature by investigating whether earnings inequality, as measured by the P90/P10 ratio, is associated with either of two indicators of social capital-active membership in organizations and interpersonal trust-in 14 European countries, including four former Soviet Bloc countries. We used analysis by Pearson's product-moment correlation to explore the potential relationships and found that the measure of earnings inequality was significantly associated with both measures of social capital. We also tentatively tested three alternative societal indicators to determine their relationship to social capital. None of the

three alternative societal indicators were found to be more strongly related to the measures of social capital than earnings inequality. 
Additional analyses of the data, the first excluding the former Soviet Bloc countries and the second also excluding Scandinavian countries, were also conducted. The results of these analyses suggested that if there is a relation between earnings inequality and social capital, country-specific economic or cultural factors may play a large role in modifying that relationship.

The remainder of this paper is divided into four main sections. The next section provides a theoretical background for the study, while section III details the methods used. The study's findings are presented in section IV and these findings are discussed in section V.

\section{Theoretical Background}

Several factors have hindered investigating the relation of social capital to income and earnings inequalities. A principal factor has been the dearth of comprehensive data available about social capital. It was not until the 1990s that ongoing projects such as the World Values Survey (Inglehart, 2000) began collecting measures of social capital from a range of countries, particularly European countries.

Another factor slowing research has been the lack of a universal definition and understanding of social capital, leaving the concept too vague, in the minds of some, for effective scientific research. However, the notion of social capital set out by Putnam (1995, 2001), which arguably remains the most prevalent definition of the term, appears to be reasonably precise: social capital consists of membership in social networks, which are in turn subject to norms of trust, goodwill, and reciprocity (Franke, 2005; Putnam, 2001). Similar to physical and human capital, social capital consists of something that may benefit its owner economically. Among the advantages of membership in social networks are access to valuable information and increased access to employment opportunities.

Many researchers, however, have studied social capital as an attribute not just of individuals, but of communities, regions, and societies. Of special interest to such collectivities is "bridging" social capital (Putnam, 1995), which refers to networks that typically include individuals from diverse backgrounds. Examples include political action alliances, educational improvement associations, and small business organizations. Bridging social capital stands in contrast to "bonding" social capital, which refers to families, groups of friends, and other social networks whose members share similar social identities (Kawachi, Kim, Coutts, \& Subramanian, 2004). In addition, "linking" social capital refers to individuals and groups with varying amounts of power who join to 
undertake civic action or promote social change (Cote \& Healy, 2001). Examples include community improvement associations and organizations concerned with ecology and sustainability.

Social capital, especially the bridging and linking type, is thought to promote a society's material and social well-being (Midgley \& Livermore, 2008). The growth of bridging and linking social capital is believed to improve economic performance, promote social issues, and positively affect all tiers of government (Halpern, 2005). The positive effect on a nation's economic development fostered by bridging social capital can be traced to its promotion of diverse networks characterized by norms of increased trust, fostering heterogeneous connections and cooperation among parties (Adam, 2008). In addition to promoting the flow of information, active participation in civic and other bridging networks promotes informal learning and learning by doing, both of which potentially benefit the economic performance of individuals (Schuller, 2000).

Measuring the social capital of a society or region is typically accomplished by aggregating the social capital of its resident individuals (Van Oorschot, Arts \& Gelissen, 2006). These measurements often focus on the number and type of voluntary networks (beyond families and personal friendships) to which individuals belong. In addition, interpersonal trust is generally regarded as an indirect measure of social capital. Kawachi (2006) maintained that this second kind of measure pertains to social capital conceived as the social cohesion of a group and contrasts it with social capital understood as individual memberships in networks. Kawachi also noted that these two conceptions can coexist, with social capital viewed as benefitting both individuals and groups. Hence, it is held that measures of interpersonal trust can be used as a proxy for social capital because viable social networks require a degree of interpersonal trust. Conversely, as interpersonal trust within a society declines, membership may decline in bridging social networks.

That income inequality in a society may be related to social capital is suggested by the findings of several studies. Kennedy et al. (1998) found income inequality strongly inversely associated with two measures of social capital-membership in voluntary organizations and interpersonal trust - among households in the United States. Notably, Larsen (2006), using data from the first and fourth waves of the World Values Survey (2009), found that during a 10-year period, except for the conservative welfare regime of Portugal, social capital as measured by interpersonal trust declined much more within liberal welfare regimes than within conservative and social democracies. Larsen argued that interpersonal trust may have decreased more in liberal countries than in conservative 
ones because of the presence of markedly more economically disadvantaged individuals, a circumstance that could foster cultural distinctions among citizens.

That a similar relationship may exist with regard to income inequality and social capital as measured by voluntary organizational membership is suggested by the circumstance that individuals are more likely to participate in civic and social activities when they have more resources (Lancee \& Van de Werfhorst, 2011). While lack of sufficient financial resources may make participation more difficult for those on the lower rungs of the ladder of economic well-being, the proportion of the populace adhering to those lower rungs is likely to grow larger as income inequality increases. Uslaner and Brown (2005) agree, holding that when high income inequality exists, both civic participation and interpersonal trust are also often low.

It is important to note, however, the possibility that causality moves in the other direction. In the case of social capital as measured by organizational membership, for example, it might be argued that increased access to information and learning are important benefits accruing to members of organizations, so that workers in societies with low organizational membership would be relatively deficient in this advantage. This, in turn, could lead to decreased upward job mobility, especially for lower income workers, which could be a factor promoting unequal earnings distribution in the society. While Larsen's (2006) study focused on the relationship of unequal income distribution to social capital, it is of interest whether a similar relationship may exist for earnings inequality, so that countries with greater earnings differentials are relatively deficient in social capital. Furthermore, though Larsen examined the relation of income inequality and social capital as measured by interpersonal trust for a number of European countries, no former Soviet Bloc countries were included in his data. It is thus also of interest to determine whether earnings inequality is related to social capital in Europe when several former Soviet Bloc countries are included in the analysis.

\section{Method}

To test the hypothesis that earnings inequality is negatively associated with social capital, 14 European countries for which recent data were available for both earnings inequality and two measures of social capital - active membership in voluntary organizations and interpersonal trust - were examined to determine the relation of earnings inequality to the social capital measures. The countries included 13 belonging to the European UnionBulgaria, Cyprus, Finland, France, Germany, Great Britain, Italy, Netherlands, Poland, Romania, Slovenia, Spain, and Sweden — and in addition, Norway. 
A single measure of how earnings are distributed in a country, the P90/P10 ratio, was considered for this study. ${ }^{1}$ This interdecile ratio serves to measure the overall earnings differentials within a nation, with higher values indicating greater earnings inequalities. The ratios were calculated by the European Commission (2005) based on results from the 2002 European Structure of Earnings Survey (Eurostat, 2011). This measure was compared to the two measures of social capital by Pearson's product-moment correlation. The two measures of social capital were taken from the fifth wave of the World Values Survey (2009), which gathered data from respondents in the 14 countries during the years 2005 to 2008 . $^{2}$ The first social capital measure, interpersonal trust, was determined by responses to World Values Survey Item V23, which asked, 'Generally speaking, would you say that most people can be trusted or that you need to be very careful in dealing with people?' Respondents could answer either 'Most people can be trusted' or 'You can't be too careful.' The interpersonal trust value for each country was the percentage of respondents in that country who answered 'Most people can be trusted.' The second social capital measure, active membership in voluntary organizations, was determined by responses to items V24 to V33, which repeatedly asked participants, 'could you tell me whether you are a member, an active member, an inactive member or not a member of...' with the interviewer then naming one of several kinds of organization: labour unions; professional organizations; church or religious organizations; sport or recreation organizations; art, music, or educational organizations; environmental organizations; political parties; charitable/humanitarian organizations; and any other organizations. Each of the kinds of organization mentioned is a locus of bridging social capital, since each kind of organization typically includes members from diverse backgrounds and ethnicities. For each nation in the survey, the percentage of respondents who reported being active in each kind of organization separately was summed to provide an indication of active organizational membership. A total of 16,274 respondents replied to the survey from all 14 countries. The number per country ranged from 1000 for Poland to 2064 for Germany. The mean number of respondents per nation for each of the 11 survey items was 1118 .

The two measures of social capital were also compared to three societal measures (percentage of urban residents, percentage of residents with tertiary education, and government spending as a percentage of GDP for each country). The rationale for doing so was to examine whether any relation found between earnings inequality and social

1. P90/P50 and P50/P10 measures of earnings distribution were also examined in relation to the two measures of social capital, with the results being similar.

2. The World Values Survey is administered by an international network of social scientists, with one principal investigator responsible for the survey data collection effort in each country. It is steered by an executive committee and secretariat and advised by a scientific advisory committee (World Values Survey, 2009). 
capital might not be most basic. Other basic societal indicators correlated with earnings differences could be more basic determinants of social capital than earnings differences. For percent urbanization, it was assumed that earnings differentials tend to decrease in more urbanized countries because urbanized areas profit from a rich variety of facilities, services, and other agglomeration benefits which offer their inhabitants increased possibilities for doing productive work that provides favourable earnings when compared to the opportunities available to people living in rural areas (Andersson, Burgess, \& Lane, 2007; Glaeser, 2011; Quigley, 1998). For the societal indicator of percent tertiary education, it was assumed that earnings differentials tend to decrease in countries with a more educated population (Alderson \& Nielsen, 2002). For government percent of GDP, it was assumed that earnings differentials tend to decrease in countries with large government expenditures because much of such spending tends to reduce differences in welfare between groups. Besides these negative relationships with earnings inequality, it can be argued that the societal indicators are likely to increase civic participation and interpersonal trust.

Data for these three societal indicators are for 2002-2009. Figures for percent urbanization were obtained from the CIA Fact Book (2011); figures for educational attainment and government spending as a percent of GDP were obtained from Eurostat (2011).

\section{Results}

As a first step in the analysis, Pearson's correlation was performed to compare the results for interpersonal trust with those for active organizational membership. Insofar as these variables both serve to measure social capital, a correlation should be seen. The result was that the two constructs were indeed found to be significantly correlated, but not strongly $(r=0.580, \mathrm{p}=0.030)$.

Table 1 presents the earnings inequality measure and the two social capital measures for each country. As shown in the table, earnings inequality was highest for Bulgaria, Poland, Romania, and Slovenia, which are the newer countries of Central and Eastern Europe, with the P90/P10 ratio being 4.4 or higher for each of these countries, with no other country exceeding 3.4. Furthermore, for at least three of these former Soviet bloc countries, scores for interpersonal trust were among the lowest, while figures for active membership in organizations were also the lowest, with the exception of Slovenia. On the other end of both spectrums, earnings inequality was lowest, hovering around 2.0, for the northern European countries of Finland, Norway, and Sweden. For these three countries, 
values for interpersonal trust were greatest and for active membership in organizations were among the greatest. For the other seven countries, earnings differentials were between those of the other two groups, while both measures of social capital were also in a mid range, though they were somewhat more scattered than for the other groups.

Table 1

Earnings inequality and two measures of social capital for 14 European countries

\begin{tabular}{lccc}
\hline \multicolumn{1}{c}{ Country } & P90/P10 & Interpersonal trust & Active in organizations \\
\hline Bulgaria & 4.40 & 22.2 & $12.0^{\mathrm{a}}$ \\
Cyprus & 3.11 & 9.9 & 62.3 \\
Finland & 1.96 & 58.9 & 78.9 \\
France & 3.36 & 18.8 & 70.2 \\
Germany & 3.15 & 36.8 & 68.7 \\
Great Britain & 3.16 & 30.5 & 126.6 \\
Italy & 2.46 & 29.2 & 70.3 \\
Netherlands & 2.75 & 45.0 & 103.1 \\
Norway & 1.98 & 74.2 & 99.5 \\
Poland & 4.67 & 19.0 & 37.8 \\
Romania & 5.09 & 20.3 & 16.3 \\
Slovenia & 4.50 & 18.1 & 71.4 \\
Spain & 3.15 & 20.0 & 42.6 \\
Sweden & 2.03 & 68.0 & 101.7 \\
\hline a Excludes responses to item V33, organizational membership, because only four participants \\
from Bulgaria replied.
\end{tabular}

This initial examination suggests that among the 14 countries examined, there existed an inverse relationship between earnings inequality and both measures of social capital, which is a finding confirmed by several other researchers (Alesina and La Ferrara, 2000; Lancee and Van de Werfhorst, 2011; Uslaner and Brown, 2005). Table 2 presents the results when the Pearson's correlation procedure is used to compare the earnings inequality measure with the two measures of social capital. As shown, earnings inequality was significantly negatively correlated with both of the social capital measures at the 0.01 level.

Because it was of interest to determine whether the three basic societal indicators were as or more strongly related to the presence of social capital in the 14 countries, as well as to determine how they were related to earnings inequality, Table 2 also shows the results when each of the three societal indicators was compared with the two social capital measures and with earnings inequality. Again, Pearson's correlation was used. The results show that both government percent of GDP and the percentage of a country's residents residing in urban areas were positively correlated with interpersonal trust and organizational membership. In addition, tertiary education percentage was positively 
related to active organizational membership. Only one of these associations rose to a statistical significance at or above the 0.01 level: percent of government GDP in relation to interpersonal trust $(\mathrm{p}=0.001)$. Overall, the associations of the three societal indicators with the two measures of social capital were weaker than the associations of earnings inequality with the social capital measures. The three societal indicators were all significantly associated with earnings inequality, with all but two of these correlations at or below the 0.01 statistical level. These correlations do raise the question of whether one should regard earnings inequality or the societal indicators as being more basically associated with social capital. However, the results of the analysis showing that the negative correlations between the social capital measures and earnings inequality were generally stronger than the positive correlations of the social capital measures with the three societal indicators suggests the possibility that the relation between earnings inequality and social capital might be more basic from an explanatory standpoint.

Table 2

Pearson's correlations between earnings inequality, social capital measures, and selected societal indicators. Correlation coefficients are shown, with p-values in parentheses

\begin{tabular}{lcccc}
\hline & Interpersonal trust & \multicolumn{2}{c}{ Active in organizations } & P90/10 \\
\hline P90/10 & $-0.741(0.002)$ & -0.703 & $(0.005)$ & - \\
Urban \% & $0.575(0.032)$ & $0.551 \quad(0.041)$ & $-0.774(0.001)$ \\
Tertiary Education \% & $0.447 \quad(0.109)$ & $0.644(0.013)$ & $-0.657(0.011)$ \\
Government \% of GDP & $0.785(0.001)$ & $0.605 \quad(0.022)$ & $-0.736(0.003)$ \\
\hline
\end{tabular}

At this point, a second stage of the analysis was performed, in which it was investigated whether country-specific economic or cultural values might play a role in shaping the found association between earnings inequality and social capital. As noted previously, it is clear from Table 1 that the four former Soviet Bloc countries not only had the highest earnings differentials on all three measures, but also tended to have markedly lower scores in both interpersonal trust and active organizational membership. To learn how large a contribution these countries made to the results, the analysis was repeated while excluding data from these countries. One result was that earnings inequality and interpersonal trust remained significantly associated, with the $r$ and $\mathrm{p}$ values for the P90/P10 measure being, respectively, -0.872 and 0.001. However, no significant relationship was found between earnings inequality and active organizational membership when the former Soviet Bloc countries were excluded from the analysis. 
Furthermore, it is evident from perusing the data in Table 1 that in the case of interpersonal trust, with or without data from the former Soviet Bloc countries, a substantial contribution to the finding of a significant association between earnings inequality and interpersonal trust was made by the three Scandinavian countries, which, like the former members of the Soviet Bloc, share economic and cultural values.

Therefore, the analysis comparing the earnings inequality to interpersonal trust was once again performed, this time excluding data from both the Scandinavian countries and the former Soviet Bloc countries. This comparison resulted in no significant association between income inequality and either measure of social capital. That is, when the seven non-former Soviet Bloc and non-Scandinavian countries-Cyprus, France, Germany, Great Britain, Italy, The Netherlands, and Spain - are considered together, there is no association between earnings inequality and either of the two measures of social capital examined in this study. For instance, while France and Great Britain had similar P90/P10 measures (3.36 and 3.16, respectively), interpersonal trust measured 18.8 for France and substantially higher for Great Britain at 30.5, while active organizational membership was at 70.2 for France and 126.6 for Great Britain. A significant relationship is found between earnings inequality and either of the social capital measures only when one or two of the three Scandinavian countries or the four former Soviet Bloc countries are included in the analysis. These results are summarized in Table 3. Overall, these later findings suggest that when investigating the association between income or earnings inequality and social capital, it is important to consider the possible effects of other country-specific variables.

\section{Table 3}

Pearson's correlations between earnings, inequality and social capital measures for 14 countries minus the former Soviet Bloc countries and for 14 countries minus the former Soviet Bloc and Scandinavian countries. The single significant correlation coefficient is shown with its $p$-value in parentheses

\begin{tabular}{lrc}
\hline \multicolumn{1}{c}{ Income inequality } & Interpersonal trust & Active in organizations \\
\hline $\begin{array}{l}\text { P90/10 for } 10 \text { non-former Soviet } \\
\text { Bloc countries }\end{array}$ & $-0.872(0.002)$ & NS \\
P90/10 for 7 non-former Soviet & & \\
$\begin{array}{l}\text { Bloc and non-Scandinavian } \\
\text { countries }\end{array}$ & NS & NS \\
\end{tabular}




\section{Concluding Remarks}

There were two stages of analysis in this study. The results in the first stage suggested that earnings inequality within a society is related to social capital as measured by interpersonal trust and active membership in organizations. Though there was evidence that the three societal indicators - percent urbanization, government percent of GDP, and percent of tertiary education - are also related to the two measures of social capital, the evidence did not warrant the supposition that earnings inequality does not play a basic explanatory role in determining a country's social capital. However, it is important to emphasize that in the original correlation analysis conducted here, any supposed direction of causality cannot be identified, whether from earnings inequality to social capital, or social capital to earnings inequality. It is also possible that some other variables could account for the association between earnings inequality and one or both measures of social capital. Indeed, the results of our test suggested that government expenditures as percent of GDP may be one such factor, especially in relation to interpersonal trust.

The study's initial findings were called into question upon further analysis. When data from the four former Soviet Bloc countries and the three Scandinavian countries were excluded from the analysis, there was no pattern of association between earnings inequality and social capital for the years investigated. These results suggested that if earnings inequality is in fact related to social capital, the relation may be substantially modified by other economic or cultural factors within the seven countries remaining in the second analysis.

Overall, further research is certainly indicated to explain the relationship between earnings inequality and social capital. Assuming adequate clarification of the concept of social capital, important information might be gathered by measuring social capital in relation to different earnings inequalities within countries instead of determining only aggregate measures of social capital. Factors other than earnings inequality are undoubtedly associated with the types and amounts of social capital in a society. For example, education and life experience have been found positively correlated with several measures of social capital (Van Oorschot et al., 2006), and the present study also found education to be positively related to trust in government and organizational activity. Regarding better understanding of the relationship between earnings inequality and social capital, connections among these variables require longitudinal studies in additional countries. Fortunately, obstacles presented by the current scarcity of authoritative data should partially disappear as new data from the World Values Survey become available. 


\section{References}

About Eurostat. (2011). Available at:

http://epp.eurostat.ec.europa.eu/portal/page/portal/about_eurostat/corporate/introd uction or http://epp.eurostat.ec.europa.eu/portal/page/portal/statistics/search_database (accessed July 1, 2011).

Adam, F. (2008). "Mapping Social Capital across Europe: Findings, Trends and Methodological Shortcomings of Cross-national Surveys. Social Science Information 47:2, 159-186

Alesina, A., \& La Ferrara, E. (2000). Participation in heterogeneous communities. Quarterly Journal of Economics, 115(3), 847-904.

Alderson, A. S., \& Nielsen, F. (2002). Globalization and the great u-turn: Income inequality trends in 16 OECD countries. American Journal of Sociology, 107(5), 1244-1299.

Andersson, F., Burgess, S., \& Lane, J. I. (2007). Cities, matching and the productivity gains of agglomeration. Journal of Urban Economics, 61(1), 112-128.

Barro, R. J. (2000) Inequality and growth in a panel of countries, Journal of Economic Growth, 5, 5-32.

Black, Duncan, \& Henderson, Vernon. (1999). A Theory of Urban Growth. Journal of Political Economy, 107(2), 252-284.

Central Intelligence Agency. (2011). The world fact book. Retrieved from https://www.cia.gov/library/publications/the-world-factbook/

Cote, S. and Healy, T. (2001) The Well-Being of Nations. The Role of Human and Social Capital, Organisation for Economic Co-operation and Development, Paris.

European Commission (2005) Employment in Europe 200: Recent Trends and Prospects. European Commission.

European Parliament (2000). Lisbon European Council 23 and 24 March 2000:

Presidency Conclusions. Available at http://www.europarl.europa.eu/summits/lis1_en.htm (accessed March 24, 2012).

Franke, S. (2005) Measurement of social capital: reference document for public policy research, development, and evaluation, Document prepared by the Policy Research Initiative Project: Social Capital as a Public Policy Tool. Available at: 
http://policyresearch.gc.ca/doclib/RD_SC_Measurement_200509_e.pdf (accessed March 24, 2012).

Glaeser, E. (2011). Triumph of the city. New York: Penguin.

Growiec, J. and Growiec, K. (2007). Social Capital, Well-Being, and Earnings: Theory and Evidence from Poland. Available from: http://ideas.repec.org/p/pra/mprapa/7071.html

Halpern, D. (2005) Social Capital. Polity Press, Cambridge, UK.

Inglehart, R. (2000, Winter). Globalization and postmodern values. The Washington Quarterly. Available at: http://www.worldvaluessurvey.org/wvs/articles/folder_published/publication_530 /files/5_globaliza.pdf (accessed March 24, 2012).

Kawachi, I. (2006). Commentary: Social capital and health: Making the connections one step at a time. International Journal of Epidemiology, 35(4), 989-993.

Kawachi, I., Kim, D., Coutts, A., \& Subramanian, S. V. (2004). Commentary: Reconciling the three accounts of social capital. International Journal of Epidemiology, 33(4), 682-690.

Kennedy, B. P., Kawachi, I., Prothrow-Stith, D., Lochner, K., \& Gupta, V. (1998). Social capital, income inequality, and firearm violent crime. Social Science \& Medicine, 47(1), 7-17.

Lancee, B., Werfhorst, H.G. van de (2011). Income Inequality and Participation: A Comparison of 24 European Countries. Amsterdam, AIAS, GINI Discussion Paper 6.

Larsen, C. A. (2006) Social capital and welfare regimes: the impact of institution dependent living conditions and perceptions of poor and unemployed, CCWS Working paper no. 2006-38, Centre for Comparative Welfare Studies (CCWS) Department of Economics, Politics and Public Administration, Aalborg University.

Lowndes. V. (2000). Women and social capital. British Journal of Political Science, 30, 533-540.

Midgley, J., \& Livermore, M. (2008) Social capital and local economic development: Implications for community social work practice. Journal of Community Practice, 5(1-2), 29-40. doi: 10.1300/J125v05n01_03

Milyo, J., \& Parnekar, I. (2003). Inequality, social capital and mortality: Re-examining the state level data. The University of Chicago, The Harris School, Working 
Paper 03-09. Available from:

http://harrisschool.uchicago.edu/about/publications/workingpapers/pdf/wp_03_09.pdf (accessed March 24, 2012).

Putnam, R. (1995) Bowling alone: America's declining social capital, Journal of Democracy 6, 65-78.

Putnam, R. (2001). Bowling alone: The Collapse and revival of American community. New York: Simon \& Schuster.

Quigley, J. M. (1998). Urban diversity and economic growth. The Journal of Economic Perspectives, 12(2), 127-138.

Reeskens, T. (2007) Defining Social Cohesion in Diverse Societies: A Durkheim-based Analysis of Trust and Normative Consensus in Ethnically Diverse Societies. Paper presented at the annual meeting of the American Political Science Association, Hyatt Regency Chicago and Sheraton Chicago Hotel and Towers, Chicago, IL, USA, August 30. Available at: http://www.allacademic.com/meta/p211577_index.html (accessed March 24, 2012).

Schuller, Tom (2000). The complementary roles of human and social capital. OECD publication. Available at: http://www.oecd.org/dataoecd/5/48/1825424.pdf (accessed March 24, 2012).

Uslaner, E., \& Brown, M. (2005). Inequality, trust, and civic engagement. American Politics Research, 33, 868-894.

van Oorschot, W., Arts, W. and Gelissen, J. (2006). Social capital in Europe: measurement and social and regional distribution of a multifaceted phenomenon, Acta Sociologica, 49, 149-167.

Wilkinson, R. and Marmot, M. Eds (2003). Social determinants of health: the solid facts. World Health Organization, $2^{\text {nd }}$ edition Available at: http://www.euro.who.int/_data/assets/pdf_file/0005/98438/e81384.pdf (accessed March 24, 2012)

World Values Survey (2009). World Values Survey Fifth Wave, 2005-2008. Available at http://www.worldvaluessurvey.org/ (accessed January 20, 2012). 